\title{
PENGARUH LANTUNAN AYAT SUCI AL-QUR'AN TERHADAP PENURUNAN TEKANAN DARAH PADA LANSIA DI PANTI JOMPO TRESNA WERDHA GAU MABAJI.
}

\author{
Mochammad Erwin Rachman ${ }^{1}$, Gifari $R A^{2}$, Sofyan $M W^{2}$ \\ 1) Bagian Neurofisiologi, Fakultas Kedokteran Universitas Muslim Indonesia \\ 2) Mahasiswa, Fakultas Kedokteran Universitas Muslim Indonesia
}

\begin{abstract}
ABSTRAK
Hipertensi masih menjadi momok menakutkan penyebab tingginya angka penyakit jantung yang berpengaruh juga terhadap tingginya angka mortalitas akibat penyakit jantung.. Dzikir berupa mendengarkan lantunan ayat suci Al-Quran merupakan salah satu bentuk relaksasi religius yang dapat memberikan respon relaksasi. Penelitian ini bertujuan mengetahui apakah ada pengaruh antara mendengarkan ayat suci Al-Qur'an terhadap penurunan tekanan darah pada lansia di Panti Jompo Tresna Werdha Gau Mabaji. Metode yang digunakan adalah menggunakan metode analitik observasional dengan pendekatan studi kuasi eksperimen. Hasil penelitian menunjukkan Hasil analisis data statistik dengan Uji Wilcoxon diperoleh hubungan yang bermakna antara mendengarkan lantunan ayat suci Al-Qur'an dengan penurunan tekanan darah dengan nilai $p$ value $=0,001$. Simpulan bahwa terdapat pengaruh yang bermakna dari mendengarkan ayat suci Al-Qur'an terhadap penurunan tekanan darah pada lansia

Kata kunci : ayat suci Al-Qur'an, penurunan tekanan darah, lansia.
\end{abstract}

\section{PENDAHULUAN}

Sistem kardiovaskular merupakan sebuah sistem yang tersusun dari organ jantung dan pembuluh darah. Pada sebuah pemeriksaan fisik yang biasa dilakukan, tekanan darah merupakan tekanan yang ditimbulkan pada dinding arteri. Ada dua jenis tekanan yang diukur yaitu tekanan sistol ialah tekanan puncak yang terjadi saat ventrikel berkontraksi. Sedangkan tekanan yang lainnya ialah tekanan diastol atau tekanan terendah yang terjadi saat jantung 
berelaksasi. Rata-rata nilai tekanan darah normal pada orang dewasa ialah 120/80 mmHg, sedangkan tekanan darah yang melampui batas normal diatas disebut hipertensi. ${ }^{1}$

Hipertensi ialah suatu kondisi dimana terjadi peningkatan tekanan darah arterial secara abnormal dan berlangsung terus menerus. Namun World Health Organisation (WHO) mengkategorikan hipertensi dengan hipertensi sistolik secara terpisah yaitu bila nilai tekanan darah sistolik lebih atau sama dengan $140 \mathrm{mmHg}$ dan atau nilai tekanan diastoliknya lebih dari $90 \mathrm{mmHg} .{ }^{2}$ Hipertensi masih menjadi momok menakutkan penyebab tingginya angka penyakit jantung yang berpengaruh juga terhadap tingginya angka mortalitas akibat penyakit jantung. ${ }^{22}$

Dalam melakukan intervensi medis, teknik relaksasi sering digunakan untuk memberikan individu kontrol diri ketika klien mengalami rasa tidak nyaman atau nyeri, juga stress fisik dan emosi klien. Teknik relaksasi ini dapat memberikan beberapa perubahan efek fisiologis dalam tubuh klien yang antara lain penurunan nadi, tekanan darah, dan pernapasan; penurunan konsumsi oksigen; penurunan ketegangan otot; penururnan kecepatan metabolism. ${ }^{7}$ Sebagai seorang muslim ada cara lain berelaksasi yang telah diajarkan oleh Allah kepada kita yaitu dzikir.

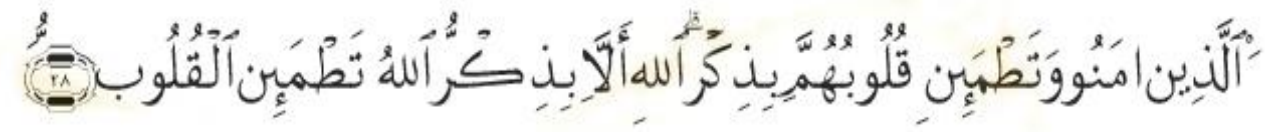

orang-orang yang beriman dan hati mereka manjadi tenteram dengan mengingat Allah. Ingatlah, hanya dengan mengingati Allah-lah hati menjadi tenteram.

\section{METODE PENELITIAN}




\section{Desain dan Lokasi Penelitian}

Penelitian ini merupakan penelitian kuantitatif, menggunakan metode kuasi eksperimen. Dengan desain penelitian berupa control group pretest-posttest design. Desain ini dilakukan dengan cara memberikan pretest (pengamatan awal) terlebih dahulu sebelum diberikan perlakuan, setelah itu diberikan perlakuan, kemudian dilakukan posttest atau pengamatan akhir. Subjek diukur tekanan darahnya sebelum dan sesudah diberikan perlakuan pada waktu penelitian dan kemudian di bandingkan, diharapkan terjadi suatu perubahan atau pengaruh pada variabel ini. Penelitian ini dilakukan di Panti Jompo Treana Werdha Gau Mabaji, Gowa, Sulawesi Selatan.

\section{Analisis Data}

Analisis univariat mendeskri-psikan karakteristik responden penelitian, yang dalam hal ini jenis kelamin, usia dan nilai tekanan darah baik sebelum ataupun sesudah intervensi, menggunakan program SPSS (Statistical Package for Social Sciences).

\section{HASIL PENELITIAN}

Data dari subyek yang berhasil dikumpulkan selama penelitian ini adalah 36 orang lansia yang terdiri dari 12 laki-laki dan 24 perempuan di Panti Jompo Treana Werdha Gau Mabaji, Gowa, Sulawesi Selatan. Analisis univariat mendeskripsikan karakteristik responden penelitian, yang dalam hal ini jenis kelamin, usia dan nilai tekanan darah baik sebelum ataupun sesudah intervensi.

Tabel 1. Deskripsi Subyek penelitian 


\section{Variabel Frekuensi (presentase (\%))}

\begin{tabular}{cr}
\hline \hline Usia & \\
$61-70$ tahun & $10(27,8 \%)$ \\
$71-80$ tahun & $19(52,8 \%)$ \\
$81-90$ tahun & $6(16,7 \%)$ \\
$91-100$ tahun & $1(2,8 \%)$ \\
Tekanan Darah pre-Intervensi & $16(44,4,2 \%)$ \\
Pre hipertensi & $15(41,7 \%)$ \\
Hipertensi Grade 1 & $5(13,9 \%)$ \\
Hipertensi Grade 2 & $12(33,3 \%)$ \\
Jenis kelamin & $24(66,7 \%)$ \\
Laki-laki & \\
Perempuan & \\
\hline Total & \\
\hline
\end{tabular}

Pada tabel 1 dapat dilihat dari total 36 responden yaitu responden dengan usia (70 tahun $=19$ orang $(52,8 \%), 60$ tahun $=10$ orang $(27,8 \%), 80$ tahun $=6$ orang $(16,7 \%)$, dan 90 tahun $=$ 1 orng $(2,8 \%))$. Nilai tekanan darah sebelum dilakukan intervensi nilai tekanan darah responden yaitu (Pre hipertensi sebanyak 16 orang (41,7\%), HT grade 1 sebanyak 15 orang $(41,7 \%)$, dan HT grade 2 sebanyak 5 orang $(13,9 \%)$ ). Berdasarkan jenis kelamin, responden berjenis responden yang berjenis kelamin perempuan berjumlah 24 orang $(66,7 \%)$ dan kelamin laki-laki berjumlah 12 orang $(33,3 \%)$.

Tabel 2 Rerata Nilai Tekanan Darah Sistol dan Diastol Subyek Penelitian 


\begin{tabular}{rcc}
\hline \multicolumn{1}{l}{ Variabel } & Sistol & Diastole \\
\hline \hline Pre intervensi & 142,83 & 82,44 \\
Post intervensi & 134,53 & 77,03 \\
Selisih sistol dan diastol & 8,3 & 5,41 \\
\hline
\end{tabular}

Pada tabel 2 menunjukan bahwa distribusi nilai tekanan darah sistol dan diastol sebelum dan sesudah intervensi. Dari data yang ada dapat disimpulkan bahwa terjadi perubahan rata-rata nilai tekanan darah baik sistol maupun diastol setelah responden diberikan intervensi. Analisis bivariat dilakukan untuk menguji hipotesis penelitian yakni pengaruh mendengarkan Ayat Suci Al quran terhadap tekanan darah pada lansia. Untuk mengetahui jenis uji apa yang digunakan untuk menganalisa data sesuai hipotesa maka digunakan uji Normalitas (uji Shapiro Wilk) dalam penelitian ini. Untuk mengetahui apakah data yang ada berdistribusi normal atau tidak. Data berdistribusi normal jika nilai $P$ value lebih besar dari 0,05. Analisa ini digunakan untuk mengetahui apakah ada pengaruh yang signifikan terhadap penurunan tekanan darah setelah diberikan intervensi. Bila nila $p$ value $<0.05$ berarti ada pengaruh intervensi terhadap penurunan tekanan darah. Selain itu, analisis ini juga digunakan untuk mengetahui apakah $\mathrm{H}_{0}$ ditolak dan $\mathrm{H}_{1}$ diterima.

Tabel 3 Analisis Pengaruh Lantunan ayat Suci Al Qur'an Terhadap penurunan Tekanan Darah pada Lansia 


\begin{tabular}{cccc}
\hline \hline Kelompok & Mean & Std. deviasi & P value \\
\hline \hline Sistol & 142,83 & 15,66 & \\
Pretest & 134,53 & 14,48 & 0,001 \\
Posttest & & & \\
& & & 0,001 \\
\hline Diastol & 82,44 & 14,53 & \\
Pretest & 77,03 & 12,45 & \\
Posttest & & & \\
\hline \hline
\end{tabular}

Uji Wilcoxon

Dari tabel diatas, terlihat bahwa ada pengaruh mendengarkan ayat suci Al-Qur'an terhadap penurunan tekanan darah pada lansia. Hal ini dapat dilihat dari perbedaan mean sistol dan diastol, sebelum dan sesudah dilakukan intervensi yang menghasilkan $P$ value 0,001 . Secara statistik hal ini berarti ada pengaruh mendengar ayat suci Al-Qur'an terhadap penurunan signifikan tekanan darah, atau dengan kata lain $\mathrm{H}_{0}$ ditolak dan $\mathrm{H}_{1}$ diterima.

\section{PEMBAHASAN}

Data yang di peroleh berdasarkan hasil penelitian terbagi 2 atas yaitu data preintervensi dan postintervensi, dimana data preintervensi ini adalah data yang di ambil pada awal pemeriksaan sebelum responden di dengarkan ayat Al-Qur'an, sedangakan data post intervensi adalah data yang di ambil pada pemeriksaan setelah responden didengarkan ayat Al-Qur'an.

Data karakteristik responden dalam penelitian ini disusun berdasarkan usia, jenis kelamin dan tekanan darah. Rentang usia antara 61 hingga 70 tahun sebanyak 12 orang, 71 hingga 80 
tahun sebanyak 23 orang dan 81 hingga 90 orang sebanayak 6 orang serta 91 hingga 100 tahun sebanyak 1 orang. Untuk jenis kelamin, pada penelitian ini jumlah perempuan lebih banyak dibandingkan dengan laki-laki dengan jumlah perempuan sebanyak 24 orang dan laki-laki sebanyak 12 orang. Sedangkan untuk yang berdasarkan nilai tekan darah jumlah responden yang menderita prehipertensi sebanyak 16 orang, hipertensi grade I sebanyak 15 orang dan hipertensi grade II sebanyak 5 orang. Responden lansia dipilih karena kelompok usia lanjut banyak mengalami hipertensi. Hal ini karena tubuh lansia mengalami penurunan baik fungsi ataupun strukturnya seperti Aterosklerosis, berkurangnya elastisitas, dan penurunan relaksasi otot polos pembuluh darah dapat menurunkan curah jantung dan meningkatkan tahanan perifer sehingga terjadi hipertensi. ${ }^{1}$ Secara insidensi pun usia lebih dari dan sama dengan 55 tahun $90 \%$ memiliki resiko terserang hipertensi. Dan di usia 55-74 tahun perempuan beresiko lebih tinggi terserang hipertensi dibandingkan laki-laki,${ }^{9}$ dengan prehipertensi sebanyak 16 orang, hipertensi grade I sebanyak 15 orang dan hipertensi grade II sebanyak 5 orang. Sedangkan setelah dilakukan intervesi maka data yang diperoleh dari tabulasai data postintervensi ada sejumlah 3 orang yang tekanan darahnya menjadi normal, prehipertensi menjadi 25 orang, hipertensi grade I menjadi 5 orang dan hipertensi grade II menjadi 3 orang.

Hasil analisa pengaruh mendengar Al-Qur'an terhadap penurunan tekanan darah secara statistik menunjukkan adanya penurunan tekanan darah sistol dan diastol yang signifikan setelah dilakukan intervensi. Hal ini dibuktikan dengan nilai $\mathrm{P}$ value $<0,05($ Sistol $=0,001$; diastol $=$ 0,001) berdasarkan hasil uji Wilcoxon. Hal ini terjadi disebabkan karena pada saat seseorang menerima stressor yang menimbulkan ketegangan dan kecemasan, saraf-saraf simpatis dalam tubuh akan bekerja dan memicu penyempitan pembuluh darah perifer dan akan menimbulkan peningkatan tekanan darah. Kemudian, apabila seseorang tersebut melakukan relaksasi, akan 
terjadi aktifasi saraf parasimpatis yang memiliki fungsi berlawanan dengan saraf simpatis. Yang berarti dalam hal ini, relaksasi dapat menjadi active coping skill pada saat seseorang menerima stressor. ${ }^{5}$ Mendengar Al-Qur'an dengan dipenuhi rasa yakin atas Allah, akan menimbulkan proses pemasrahan diri kepada Sang Pencipta yang akan membawa kondisi pasif bagi tubuh si pembaca. Selain itu, mendengar Al-Qur'an seperti ini juga akan menimbulkan efek plasebo yang menyehatkan dan mendengar Al-Qur'an sendiri dapat menjadi salah satu bentuk relaksasi disebut dengan metode meditasi transendensi. Relaksasi ini tidak berfokus pada proses pengenduran otot atau proses pelemasan fisik lainnya, melainkan pada frase yang diucapkan berulang dengan ritme yang teratur disertai kepasrahan diri pada Tuhan. Pada saat dilakukan pengulangan frase tersebut, tubuh akan terjadi proses relaksasi yang pada dasarnya ialah mengaktifkan saraf-saraf parasimpatis yang akan menurunkan semua respon tubuh yang telah dinaikan oleh saraf simpatis. ${ }^{5}$ Saat melakukan relaksasi, ketegangan pikiran akan berkurang dan mengurangi respon "fight or flight", sehingga jumlah adrenalin yang dilepas pun ikut berkurang dan sirkulasi darah pun ikut membaik. ${ }^{10}$ Membaca ataupun mendengarkan ayat suci Al-Qur'an dengan dipenuhi rasa yakin atas Allah, akan menimbulkan proses pemasrahan diri kepada Sang Pencipta yang akan membawa kondisi pasif bagi tubuh responden. Selain itu, membaca ataupun mendengarkan ayat suci Al-Qur'an akan menimbulkan efek plasebo yang menyehatkan dan dapat menjadi salah satu bentuk relaksasi disebut dengan metode meditasi transendensi. ${ }^{5}$

Hasil peneitian ini sejalan dengan hipotesis penelitian yang diperkuat data statistik menunjukkan bahwa mendengarkan ayat suci Al-Qur'an dapat menurunkan tekanan darah pada lansia. Hal ini sejalan dengan penelitian sebelumnya yang dilakukan oleh Sudiarto, dkk (2007) tentang pengaruh terapi relaksasi meditasi terhadap penurunan tekanan darah pada lansia di wilayah Panti Jompo Werdha Tresna Gau Mabaji, Kabupaten Gowa. 


\section{KESIMPULAN}

Terdapat pengaruh yang bermakna dari mendengarkan lantunan ayat suci Al-Qur'an terhadap tekanan darah pada lansia.

\section{DAFTAR PUSTAKA}

1. Depkestzer, Suzenne C. 2002. Buku Ajar Medikal-Bedah Brunner \& Suddarth Vol.1 Ed.8. Jakarta: EGC.

2. Brasher, Valentina L. 2008. Aplikasi klinis patofisiologi pemeriksaan dan manajemen. Jakarta : EGC.

3. Depkes RI, 2010. Hipertensi faktor risiko utama penyakit kardiovaskular, http://www.depkes.go.id diperoleh tanggal 26 februari 2016.

4. Dalimartha, Setiawan dkk. 2006. Care yourself . Hipertensi. Jakarta : Penebar plus.

5. Purwanto, setyo. 2008. Relaksasi dzikir. Suhuf vol. XVIII.

6. Pargament, Wachholtz. 2005. Is spirituality a critical ingredient of meditation? Comparing the effect of spiritual meditation, secular meditation, and relaxation on spiritual, psychological, cardiac, and pain outcome. Journal of behavior medicine vol.28.

7. Potter \& Perry. 2006. Fundamentals of Nursing: Concepts, Process, and Practice (2th Ed). St. Louis. Baltimore. Toronto: Mosby Company.

8. Tambayong, Jan. 2000. Patofisiologi untuk keperawatan. Jakarta : EGC. Corwin, Elizabeth J. Buku saku patofisiologi. Jakarta : EGC. 2009.

9. Vikrant, Tiwari SC. 2001. Essential hypertension pathogenesis and pathophysiology. Journal Indian Academy of clinical medicine vol.2.

10. Kowalski, Robert E. 2010. Terapi hipertensi : program 8 minggu menurunkan tekanan darah tinggi dan mengurangi resiko serangan jantung dan stroke secara alami. Bandung : PT. Mizan Pustaka. 
11. Ibn nasir, Badr. 2012. Keutamaan membaca dan menghapal AlQur'an.Keutamaan_membaca_dan_mengkaji_alquran.

12. Hawari, Dadang. 2005. Dimensi Religi Dalam Praktek Psikiatri dan psikologi. Jakarta : Balai Penerbit Fakultas Kedokteran UI.

13. Ja'fari, Albukhori. 2005. Shohih Bukhori juz as-sadis almujallidu al-tsalits. Berikut : Daar ibn ashoshoh.

14. Yahya, Muhyidin Abi Zakariya. 2005. sRiyadus Shalihin.indonesia : Daar al-ihyya al-kitab alarabiyyah.

15. Sudiarto, dkk. 2006. Pengaruh Terapi Relaksasi Meditasi Terhadap Penurunan Tekanan Darah Pada Lansia Dengan Hipertensi di Wilayah Binaan Rumah Sakit Emanuel Klampok. Banjarnegara. Jurnal Keperawatan Soedirman. Vol 2. 